\title{
PENGARUH PAMALI SEBAGAI KEARIFAN LOKAL DALAM MEWUJUDKANNILAI DAN NORMA DALAM KEHIDUPAN SOSIAL GENERASI Z
}

\author{
Abu Hanif Muhammad Syarubany, Mazi Prima Karunia Azzahra, Rizky Sri Rahayu, \& \\ Suhandoyo Prayoga \\ Institut Teknologi Bandung \\ Email : hanifsarubany10@gmail.com
}

\begin{abstract}
Abstrak
Indonesia adalah negara yang luas dan memiliki banyak ragam budaya. Salah satu hasil budaya yang dimiliki adalah pamali (tabu). Pamali sebagai kearifan lokal yang bersumber dari pengetahuan setempat, kini telah menjadi identitas kebudayaan Indonesia. Adanya budaya ini, mampu mendinamisasi kehidupan sosial yang penuh keadaban dan kearifan. Penelitian ini bertujuan untuk mengetahui keterkaitan pamali dengan perwujudan nilai dan norma dalam kehidupan bermasyarakat dan mengetahui tingkat eksistensinya dalam masyarakat. Metode yang digunakan dalam penelitian ini adalah survei dan kajian literatur. Metode survei akan dilakukan kepada masyarakat Indonesia guna menggali informasi mengenai pamali yang ada di daerah setempat. Hasil penelitian ini yakni masih eksisnya pamali di masyarakat dan adanya korelasi positif antara pamali dengan nilai dan norma dilihat dari segi implementasinya dalam kehidupan.
\end{abstract}

Kata kunci: kebudayaan, masyarakat, nilai, pamali

\begin{abstract}
Indonesia is a vast country and has many cultures. One of the cultural products that is owned is pamali (taboo). Pamali as local wisdom sourced from local knowledge, has now become the identity of Indonesian culture. The existence of this culture is able to dynamize social life which is full of civility and wisdom. This study aims to determine the relationship between pamali and the embodiment of values and norms in social life and to determine the level of their existence in society. The method used in this research is a survey and literature review. The survey method will be carried out to the Indonesian people in order to obtain information about the pamali in the local area. The results of this study are the existence of pamali in society and there is a positive correlation between pamali and values and norms in terms of their implementation in life.
\end{abstract}

Keywords: culture, pamali, public, score

\section{PENDAHULUAN}

Sebagai negara yang dikenal memiliki suku budaya dan adat istiadat yang beragam, menjadikan Indonesia memiliki kearifan lokal yang beragam pula. Kearifan lokal merupakan bagian dari budaya suatu masyarakat yang tidak dapat dipisahkan dari bahasa masyarakat itu sendiri. Hal ini merupakan warisan dari orang terdahulu. Kearifan lokal terdiri dari dua hal yakni kearifan (wisdom) dan lokal (local) (Rahmelia, 2021).

Menurut KBBI, kearifan memiliki arti kebijaksanaan; kecendekiaan; mengajar dan mendidik anak-anak sangat membutuhkan kearifan sedangkan lokal berarti terjadi (berlaku, ada, dan sebagainya) di satu tempat, tidak merata; setempat. Sehingga dapat diartikan bahwa kearifan lokal adalah budaya yang berkembang di masyarakat. Kearifan lokal atau local wisdom ini biasanya diwariskan secara turun temurun dari generasi kegenerasi melalui cerita dari mulut ke mulut. Banyak sekali budayabudaya yang tersebar di Indonesia dan memiliki nilai luhur yang tinggi (Rachman, Ryan, et al., 2021) (Rachman, Nurgiansah, et al., 2021).

Sebagai masyarakat yang berbudaya, tak lepas dari sangkut paut nilai dan norma. Adanya nilai dan norma ini mampu memberi tuntunan dan sebagai pengikat. 
Pada perkembangannya, norma itu diartikan sebagai suatu ukuran patokan bagi seseorang dalam bertindak atau bertingkah laku dalam masyarakat. Salah satu norma yang ada di masyarakat adalah norma kesopanan. Norma kesopanan adalah aturan hidup bermasyarakat yangmengatur tentang tingkah laku yang baik dan tidak baik baik, patut dan tidak patut dilakukan, yang berlaku dalam suatu lingkungan masyarakat atau komunitas tertentu. Norma kesopanan ini biasanya berasal dari adat istiadat, budaya, atau nilai-nilai masyarakat. Adanya norma ini mampu mendotong seseorang untuk berbuat baik dan sopan santun serta beretika (Risyda, 2018) (Dewantara \& Nurgiansah, 2021b).

Pamali merupakan salah satu hasil kearifan lokal Indonesia. Pamali dibuat oleh masyarakat melalui pengalamanpengalaman mereka dan diintegrasikan dalam sebuah larangan atau pantangan. Pamali sudah ada sejak zaman dahulu dan banyak diterapkan oleh masyarakat (Dewantara \& Nurgiansah, 2021c). Banyak yang berpendapat bahwa pamali hanyalah mitos belaka dan hanya dibuat-buat, namun ada juga sebagian masyarakat yang mempercayai dan menerapkan dalam kehidupan kesehariannya.dapat dikatakan bahwa pamali adalah sebagai suatu larangan yang jika dilarang akan mendatangkan celaka (Dewantara, Nurgiansah, et al., 2021). Pamali juga berperan sebagai aturan-aturan masyarakat yang mengatur segala pola hidup masyarakatnya diluar kepercayaan masyarakat terhadap agama. Tidak dapat dipastikan secara pasti kapan dan di mana pamali ditemukan namun keberadaan pamali hampir semua ada di berbagai suku di Indonesia. (Widiastuti, 2015) (Dewantara \& Nurgiansah, 2021a).

Bagi Generasi $\mathrm{Z}$ yang dilingkupi dengan kehidupan modern, mungkin banyak yang tidak mengenal pamali. Oleh karena itu, kami melakukan penelitian yang berjudul "Pengaruh Pamali Sebagai Kearifan
Lokal dalam Mewujudkan Nilai dan Norma dalam Kehidupan Sosial Generasi Z" untuk menentukan pengaruh pamali dalam mewujudkan nilai dan norma dalam kehidupan sosial generasi $\mathrm{Z}$ serta menentukan eksistensi pamali di kalangan generasi Z (Dewantara, Hermawan, et al., 2021).

Penelitian ini bertujuan untuk menentukan pengaruh pamali dalam mewujudkan nilai dan norma dalam kehidupan sosial generasi $\mathrm{Z}$ dan menentukan eksistensi pamali di kalangan generasi Z. Manfaat dari penelitian ini adalah dapat mengetahui pengaruh pamali dalam mewujudkan nilai dan norma dalam kehidupan sosial generasi Z dan mengetahui eksistensi pamali di kalangan generasi Z.

\section{METODE PENELITIAN}

Pada penelitian ini, metode yang digunakan adalah metode survey dan kuesioner sebagai instrumen penelitian yang telah disebar ke berbagai mahasiswa dengan rentang umur dari 16 tahun sampai 25 tahun serta sudah berhasil mendapatkan jumlah responden sebesar 75 orang.

Penelitian ini menggunakan metode deskriptif analitis dan kualitatif. Dengan penelitian ini, orang yang memiliki tujuan yang dengan peneliti dapatmembandingkan hasil penelitian untuk menunjukkan pengaruh pamali dalam mewujudkan nilai dan norma terhadap kehidupan sosial Generasi Z.

Penelitian deskriptif analitis adalah suatu metode dalam penelitian status kelompok manusia, suatu objek, suatu set kondisi, suatu sistem pemikiran, ataupun suatu kelas peristiwa pada masa sekarang Muhammad Nazir (2003:54) (Nurgiansah, 2021c). Penerapan metode ini berguna untuk menjelaskan hubungan antara variabel satu sama lain dan mendapatkan solusi yang tepat.

Selain itu, penelitian kualitatif menurut Sugiyono (2016:9) dalam 
(Nurgiansah, 2020) metode penelitian kualitatif adalah metode penelitian yang digunakan untuk meneliti pada kondisi obyek yang alamiah dimana peneliti adalah sebagai instrumen kunci.

\section{HASIL PENELITIAN DAN PEMBAHASAN Hasil Penelitian Nilai dan Norma Pamali}

Generasi Z adalah generasi yang lahir pada tahun 1997 sampai dengan tahun 2012. Generasi Z merupakan sebuah generasi yang berkembang atau bertumbuh di tengah paparan internet,media sosial, dan teknologi. Di Indonesia sendiri Generasi Z mendominasi dari jumlah penduduk Indonesia. berdasarkan Hasil Sensus Penduduk 2020, penduduk Indonesia terdapat 74,93 juta atau $27,94 \%$ dari total Penduduk Indonesia. Generasi ini tumbuh bersama di Indonesia yangmemiliki kearifan lokal yang sudah diwarisi oleh leluhur. Kearifan lokal ini merupakan pamali.

Berikut ini merupakan contoh - contoh pamali yang tersebar di kalangan masyarakat

1. "Jangan menyapu malam hari, pamali lhoo!!"

2. "Anak perawan gak boleh duduk depan pintu"

3. "Jangan duduk di bantal, nanti bisulan"

4. "Jangan foto bertiga, nanti yang tengah meninggal"

5. "Jangan buang nasi, nanti nasinya nagis"

Pada dasarnya penanaman etika moral dan akhlak dapat diterapkan kepada anak sejak dini. Karakter yang ditanamkan lebih kepada kebiasaan. Kebiasaan yang terus menerus dilakukan oleh anak, seperti pamali yang merupakan penanaman dari karakter dari dini karena pamali merupakan budaya turun temurun yang sudah diajarkan dari sejak kecil termasuk masa kecil generasi Z (Nurgiansah, 2021a).

Nilai merupakan pandangan seseorang yang baik atau buruk, nilai merupakan dasar atau terbentuknya suatu norma. Nilai yang termasuk pamali adalah nilai mendarah daging, yaitu nilai yang sudah menjadi kebiasaan yang sudah terbentuk sedari kecil. Ketika nilai ini tidak dijalankan maka akan menimbulkan rasa bersalah. Pada pamali apabila setiap orang yang melanggar selalu mendapatkan balasan yang tidak diinginkan. Dari penanaman nilai pamali tersebut kita dibiasakan untuk tidak melanggar pamali yang ada untuk tidak mendapatkan balasan yang tidak diinginkan (Nurgiansah, 2021d).

Pamali merupakan norma adat yang tidak tertulis. Norma tidak tertulis terbentuk karena sebuah kebiasaan. Norma tidak tertulis ini dilaksanakan atas kesadaran setiap individu untuk mewujudkan ketertiban. Untuk itu, norma tidak tertulis diakui dan disepakati kebenarannya oleh masyarakat secara alami melalui interaksi yang berlangsung lama. Masyarakat mengetahui pamali dan mempercayainya karena pamali sudah dilakukan secara turun-temurun (Nurgiansah, 2021b).

Mencoba untuk tidak melanggar pamali menjadi sebuah kebiasaan dalam masyarakat Indonesia karena melanggar pamali dianggap tidak sopan, walaupun pamali bukanlah peraturan resmi atau bahkan banyak dari generasi Z yang kurang percaya atas adanya mitos pamali. Namun, karena sudah menjadi kebiasaan hal ini menjadi norma kesusilaan dimana pamali dimana kita tidak melakukan apa yang dilarang oleh pamali karena apabila dilanggar kita merasa kurang sopan, hal ini juga dirasakan masyarakat dimana mereka tidak dibatasi oleh pamali dalam kehidupan mereka sehari-hari.

\section{Pembahasan}

\section{Pandangan Masyarakat Generasi Z terhadap Pamali}

Berdasarkan survey yang telah disebarkan kepada masyarakat generasi Z, 
sebanyak 90,5\% orang menyatakan bahwa pada daerah tempat responden berada terdapat pamali yang sudah dilestarikan. Sebanyak 67,6\% pamali tersebut diajarkan oleh orangtua. Sementara itu, sisanya berasal dari teman dan internet. Dengan adanya fakta tersebut, kita bisa tahu bahwa sebagian besar masyarakat daerah yang ada di Indonesia telah diajarkan pamali sejak dini melalui ajaran orangtuanya. Hal tersebut diperkuat dengan fakta surveyyang menyatakan bahwa sebagian besar responden sebesar $86,6 \%$ menyatakan bahwa mereka sangat tahu terhadap istilah pamali.

Akan tetapi, sebagian besar responden sebanyak $76 \%$ juga menyatakan bahwa mereka sangat tidak percaya terhadap ajaran pamali walaupun sebanyak $74,7 \%$ dari responden percaya bahwa pamali itu termasuk budaya. Berdasarkan fakta tersebut, hal tersebut tentu sangat wajar mengingat ajaran pamali berisi makna-makna yang tidak wajar, misalnya "Jangan duduk di bantal, nanti bisulan". Secara logika, tidak mungkin seseorang akan memiliki bisulan apabila melakukan aktivitas duduk di bantal.

Akan tetapi, maksud dari kalimat pamali tersebut mengisyaratkan bahwa kita hendaknya tidak duduk di bantal karena bantal tidak layak untuk dijadikan tempat duduk. Apabila seseorang duduk di bantal, maka fungsionalitas asli dari bantal untuk menjadi tempat tidurnya kepala akan menjadi kehilangan esensinya. Dengan demikian, pamali tersebut muncul atas dasar menakut-nakuti seseorang agar menghindari kebiasaan buruk agar membuat suatu larangan menjadi efektif.

Berdasarkan esensi dari adanya pamali, pamali muncul sebagai larangan yang efektif dengan cara menakut-nakuti seseorang untuk menghindari kebiasaan buruk. Akan tetapi, adanya pamali tersebut tidak efektif dalam mengubah kebiasaan generasi $\mathrm{Z}$ sehari-hari. Hal tersebut didukung dengan adanya fakta survey yang menyatakan bahwa sebanyak $66,2 \%$ responden menyatakan bahwa pamali tidak berdampak pada kebiasaan sehari-hari mereka.

Selain itu, sebagian besar responden sebanyak $62,2 \%$ tidak menerapkan pamali yang ada dalam kehidupan sosial mereka. Dengan adanya fakta tersebut, kita tahu bahwa ajaran pamali tidak efektif untuk mempengaruhi kehidupan sosial generasi Z . Hal tersebut dikarenakan masyarakat generasi $\mathrm{Z}$ dapat berpikir kritis dalam berbagai situasi, sehingga apabila mereka diajarkan sesuatu berupa larangan, akal mereka dapat memikirkan setiap masukanmasukan yang telah diajarkan kepada mereka.

Mereka dapat menyaring mana informasi yang benar dan mana informasi yang salah. Jadi, karena pamali berisi larangan-larangan tentang kebiasaan buruk yang diisi dengan kesesatan yang tidak masuk akal, masyarakat generasi $\mathrm{Z}$ tetap dapat menyaring informasi yang salah tersebut sehingga mereka tidak akan menerapkannya pada kehidupan sosial mereka. Meskipun demikian, sebagian besar sebanyak $82,8 \%$ responden masyarakat generasi $\mathrm{Z}$ setuju bahwa pamali memiliki dampak positif. Hal tersebut diperkuat dengan adanya fakta survey yang menyatakan bahwa sebagianbesar sebanyak $66,2 \%$ responden menyatakan bahwa ajaran pamali tidak perlu dihapus untuk generasi berikutnya.

Berdasarkan fakta yang tertera pada survey, maka dapat disimpulkan bahwa sebagian besar masyarakat generasi $\mathrm{Z}$ masih tetap menyadari bahwa terdapat budaya pamali yang ada di sekitar mereka. Mereka sadar bahwa pamali tersebut harus tetap dilestarikan dan tetap dibudidayakan. Mereka juga menginginkan bahwa ajaran pamali tetap perlu diturunkan untuk generasi berikutnya demi melestarikan budaya indonesia yang penuh dengan 
kemakmuran dan penuhdengan tatakrama. Pamali ini tidak membatasi kebebasan dalam kehidupan sosial mereka. Hal tersebut dibuktikan dengan adanya fakta survey yang menyatakan bahwa terdapat sekitar 65\% responden survey yang tidak setuju bahwa pamali dapat membatasi kebebasan dalam kehidupan sosial mereka. Dengan demikian, ajaran pamali ini harus tetap diturunkan dari generasi ke generasi demi melestarikan adanya budaya pamali di Indonesia yang penuh dengan keunikan

\section{Pengaruh Pamali terhadap kehidupan sosial Generasi Z}

Berdasarkan survey yang telah disebar ke masyarakat generasi Z, terdapat fakta yang mengejutkan bahwa ternyata dampak sosial yang ditimbulkan akibat adanya pamali tersebut hampir nihil. Padahal, pamali berisi larangan yang disertai dengan kebohongan yang cukup menakutkan. Apabila pamali tersebut diajarkan pada anak-anak, maka anak-anak akan langsung percaya dan tidak berani untuk melakukan apa-apa yang dilarang oleh pamali. Akan tetapi, hal tersebut rupanya tidak berlaku untuk masyarakat remaja atau masyarakat generasi $\mathrm{Z}$.

Hal tersebut dikarenakan masyarakat generasi $\mathrm{Z}$ sudah mengenal dunia teknologi. Mereka mampu mendapatkan informasi dari berbagai hal, terutama internet. Asupan informasi yang disajikan oleh internet terus menerus dikonsumsi oleh mereka setiap harinya. Dengan adanya informasi yang berlimpah tersebut, mereka cenderung tidak dapat menerima informasi, terutama larangan yang isinya tidak masuk akal. Apalagi larangan tersebut merupakan suatu pamali yang tidak relevan dalam kehidupan Generasi Z. 86,5\% dari responden menjelaskan bahwa Generasi Z berada di lingkungan yang tidak memaksanya untuk mengikuti pamali tersebut. Berbalik dengan jumlah pamali yang tersebar dalam lingkungan yang cukup banyak untuk dapat didengar Generasi Z.

Generasi Z memiliki rasa untuk bebas dari pamali yang ada. Kebanyakan Generasi $\mathrm{Z}$ berada pada lingkungan yang tidak terlalu tegas dalam hal penerapan pamali yang ada. Asal daerah responden dapat dikatakan sebagai tempat yang kurang kental budaya pamali. Dapat dilihat dari hasil survey bahwa hampir semua responden berada pada kota-kota besar di Indonesia seperti Bandung, Jakarta, Palembang, Padang, Tangerang, Surabaya sehingga pamali ini tidak berdampak pada kehidupan seharihari Generasi Z.

Hanya 33,8\% responden mengatakan bahwa pamali berdampak pada kehidupan sehari-harinya. Hal ini bisa terjadi dari kebiasaan semasa kecil yang masih dilakukan hingga saat ini. Kita bisa mengutip salah satu contoh pamali, yakni "Kalau makan nasi harus dihabiskan, kalau tidak nanti nasinya nangis". Kalimat pamali tersebut merupakan kalimat yang paling terkenal. Apabila kita memperhatikan kalimat tersebut, kita dapat dengan mudah mengetahui bahwa tidaklah mungkin nasi akan menangis apabila nasi yang hendak dimakan tidak dihabiskan. Akan tetapi, maksud dari kalimat pamali tersebut adalah suatu hal yang sederhana yang menyarankan bahwa apabila seseorang hendak memakan nasi, maka nasi tersebut harus dihabiskan. Hal tersebut dilakukan agar makanan tidak mubazir. Kita juga tahu bahwa membuang-buang makanan sisa adalah sesuatu yang buruk. Selain kalimat pamali di atas, terdapat contoh kalimat pamali yang maknanya sulit dicerna. Misalnya adalah "Jangan duduk di atas meja, pamali.

Lingkungan sosial tempat Generasi Z berada bersifat suportif terhadap kehidupan sehari-hari Generasi Z, 90,5\% responden tidak pernah terkena dampak sosial dari pelanggaran pamali yang terjadi di sekitar daerahnya. Hal ini berlawanan dengan, fakta bahwa $82,2 \%$ responden mengatakan 
bahwa pamali berdampakpositif. Generasi Z memiliki karakter unik yang berbeda dengan generasi sebelumnya. Dengan kehidupan sehari-hari yang lebih berdasar fakta tetapi menginginkan budaya pamali ini tetap ada dan lestari di Indonesia.

\section{Pengaruh Pamali terhadap kehidupan sehari-hari Generasi Z}

Dari pertanyaan survey "Apakah kamu menerapkan pamali-pamali yang ada dalam kehidupan sosialmu?" 62,2\% menjawab sebagian dari pamali yang ada, $33,8 \%$ tidak sama sekali menerapkannya dan 4,1\% menjawab ya. Hal ini mengartikan pamali sedikit memengaruhi sebagian Generasi Z dalam melakukan kegiatan atau kebiasaan sosial rutinnya. Pamali yang memiliki maksud yang positif tentunya akan membuat Generasi Z mengikutinya tanpa perlu mengetahui makna filosofis yang dimaksudkan. Diperkuat dengan 82,2\% responden mengatakan bahwa pamali memberikan dampak positif. Pamali yang bermakna ambigu atau sulit diartikan cenderung tidak diterapkan Generasi Z karena tidak mudah memercayai sesuatu tanpa alasan yang jelas dan bisa berdampak pada nilai dan norma yang berlaku pada daerah sekitar.

Banyaknya responden yang menjawab pamali sebagai budaya sebesar $74,7 \%$ walaupun $76 \%$ responden hampir tidak memercayai pamali tersebut dan $33,8 \%$ responden sama sekali tidak menerapkan pamali. Hal inimengindikasikan bahwa pamali di Indonesia bagi Generasi Z menjadi ciri khas atau kearifan lokal yang dimiliki indonesia atau daerah tertentu. Dengan penerapan yang sebagian atau seluruhnya pada tempat-tempat tertentu yang kental budaya-budaya pamali.

Pamali yang ada di masyarakat dengan maksud yang baik untuk menjaga nilai dan norma dalam kehidupan sosial, dengan $66,2 \%$ responden setuju untuk tetap melestarikan budaya pamali yang ada dan persebaran terbanyaknya melalui orang tua sebesar $67,6 \%$ akan mungkin untuk terus dan tetap tersampaikan pada generasigenerasi berikutnya.

\section{KESIMPULAN}

Berdasarkan data survey, dapat disimpulkan bahwa pamali merupakan suatu instrumen yang berisi tentang aturan dan larangan yang telah diajarkan kepada masyarakat generasi $\mathrm{Z}$ sejak dini oleh orangtuanya. Sebagian besar dari mereka menganggap bahwa pemberlakuan pamali sejak dini tidak mempengaruhi kehidupan sosial mereka. Oleh karena itu, dapat disimpulkan bahwa pamali tidak mempengaruhi kehidupan sosial dari masyarakat generasi Z.

Pamali sudah ada di masyarakat sejak zaman dahulu. Pamali merupakan norma adat yang tidak tertulis. Norma tidak tertulis terbentuk karena sebuah kebiasaan. Norma tidak tertulis ini dilaksanakan atas kesadaran setiap individu untuk mewujudkan ketertiban. Pamali tetap menjadi warisan budaya dari leluhur yang tetap diajarkan kepada masyarakat sejak dini. Walaupun pamali memiliki pengaruh yang hampir nihilterhadap kehidupan sosial berdasarkan pandangan dari masyarakat generasi Z,pamali ini nyatanya efektif dalam menciptakan suatu nilai dan norma yang aman dan tentram dalam kehidupan bermasyarakat. Oleh karena itu, dapat disimpulkan bahwa pamali memiliki korelasi yang kuat terhadap tumbuhnya nilai dan norma yang berlaku di masyarakat.

Sebagian besar masyarakat generasi

Z menganggap bahwa pamali tidak mempengaruhi kehidupan sosial mereka. Meskipun demikian, sebagian besar dari mereka juga setuju bahwa pamali harus tetap dijaga, dilestarikan, dan diwariskan. Hal tersebut dikarenakan ajaran pamali sangat efektif dalam menuntun seseorang menjadi pribadi dengan tingkah laku yang baik sejak dini. 
Sebagai masyarakat indonesia, kita hendaknya tetap melestarikan pamali sebagai budaya yang telah diwariskan turun-temurun sejak dahulu. Cara mewariskannya adalah dengan tetap mengajarkan pamali kepada seseorang sejak dini. Pada saat manusia masih berumur anak-anak, mereka cenderung masih polos dan percaya terhadap setiap perkataan atau ucapan dari orangtuanya. Oleh karena itu, hendaknya orang tua memberikan anaknya untuk tetap taat aturan dengan cara mengajarkannya tentang aturan-aturan atau tabu yang ada di pamali.

Sebagai masyarakat generasi Z, kita tidak boleh mengabaikan pamali begitu saja. Kita boleh tidak percaya terhadap hal- hal mistis yang ada di pamali. Akan tetapi, kita harus percaya bahwa larangan pamali tersebut baik untuk kita tetap patuhi untuk menjadi pribadi yang lebih baik dan taat aturan. Oleh karena itu, hendaknya kita tetap melestarikan pamali dengan cara menghindari larangan-larangan atau tabu yang ada di pamali.

\section{DAFTAR PUSTAKA}

Dewantara, J. A., Hermawan, Y., Yunus, D., Prasetiyo, W. H., Efriani, Arifiyanti, F., \& Nurgiansah, T. H. (2021). Anti-Corruption Education as an Effort to Form Students With Character Humanist and Law-Compliant. Jurnal Civics: Media Kajian Kewarganegaraan, 18(1), 70-81.

Dewantara, J. A., \& Nurgiansah, T. H. (2021a). Building Tolerance Attitudes Of PPKN Students Through Multicultural Education Courses. Jurnal Etika Demokrasi, 6(1), 103-115.

Dewantara, J. A., \& Nurgiansah, T. H. (2021b). Peningkatan Keaktifan Belajar Melalui Penerapan Model Picture And Picture Dalam Pembelajaran PPKn di Sekolah Dasar. Jurnal Publikasi Pendidikan, 11(3), 234-241.

Dewantara, J. A., \& Nurgiansah, T. H. (2021c). Strengthening Pancasila Values During the Covid19 Pandemic. Edukatif: Jurnal Ilmu Pendidikan, 3(4), 2411-2417.

Dewantara, J. A., Nurgiansah, T. H., \& Rachman, F. (2021). Mengatasi Pelanggaran Hak Asasi Manusia dengan Model Sekolah Ramah HAM (SR-HAM). Edukatif: Jurnal Ilmu Pendidikan, 3(2), 261-269.

KBBI, 2016. Kamus Besar Bahasa Indonesia (KBBI). [Online] Available at: https://kbbi.kemdikbud.go.id/entri/lokal [Diakses 22 November 2021]

KBBI, 2016. Kamus Besar Bahasa Indonesia (KBBI). [Online] Available at: https://kbbi.kemdikbud.go.id/entri/kearifan [Diakses 22 November 2021]

Nurgiansah, T. H. (2020). Pelatihan Penulisan Artikel Ilmiah Bagi Mahasiswa PPKn Universitas PGRI Yogyakarta. JNPM: Jurnal Nasional Pengabdian Masyarakat, 1(1), 16-23.

Nurgiansah, T. H. (2021a). Partisipasi Politik Masyarakat Sleman di Masa Pandemi Covid-19 dalam Konteks Pendidikan Kewarganegaraan. Jurnal Civic Hukum, 6(1), 1-9.

Nurgiansah, T. H. (2021b). Pelatihan Penelitian Tindakan Kelas Bagi Guru Pendidikan Kewarganegaraan Di Sekolah Menengah Atas Se-Kabupaten Bantul. BERNAS: Jurnal Pengabdian Kepada Masyarakat, 2(1), 28-33. https://doi.org/10.31949/jb.v2i1.566

Nurgiansah, T. H. (2021c). Pemanfaatan E-Learning Dalam Pembelajaran Pendidikan Kewarganegaraan. JINTECH: Journal of Information Technology, 2(2), 138-146.

Nurgiansah, T. H. (2021d). Petuah Pendidikan Kewarganegaraan Dalam Kontestasi Politik. AoEJ: Academy of Education Journal, 12(1), 39-47.

Rachman, F., Nurgiansah, T. H., \& Kabatiah, M. (2021). Profilisasi Pendidikan Kewarganegaraan dalam Kurikulum Pendidikan Indonesia. Edukatif: Jurnal Ilmu Pendidikan, 3(5), 2970-2984.

Rachman, F., Ryan, T., Kabatiah, M., Batubara, A., Pratama, F. F., \& Nurgiansah, T. H. (2021). Pelaksanaan Kurikulum PPKn pada Kondisi Khusus Pandemi Covid-19. Jurnal Basicedu, 
$5(6), 5682-5691$.

Rahmelia, S. (2021). Pemaknaan Mahasiswa Terhadap Narasi Konflik Beragama. Jurnal Kewarganegaraan, 5(1), 45-54.

Risyda, N. Reposiori IAIN Kudus BAB II. 2018

Widiastuti, H. Pamali dalam Kehidupan Masyarakat Kecamatan Cigugur Kabupaten Kuningan (Kajian Semiotik dan Etnopedagogi). Vol. 6, No. 1, April 2015. 